\title{
Effect of equal-channel angular pressing (ECAP) and current density of cathodic hydrogen charging on hydrogen trapping in the low-alloy steel
}

\author{
E. D. Merson ${ }^{\dagger, 1}$, P. N. Myagkikh¹, G. V. Klevtsov' ${ }^{1}$ D. L. Merson¹, A. Yu. Vinogradov ${ }^{2}$ \\ †Mersoned@gmail.com
}

\begin{abstract}
${ }^{1}$ Institute of Advanced Technologies, Togliatti State University, 14 Belorusskaya St., Togliatti, 445667, Russia ${ }^{2}$ Department of Mechanical and Industrial Engineering, Norwegian University of Science and Technology, NTNU, Trondheim, N-7491, Norway
\end{abstract}

Owing to the outstanding mechanical properties, the steels and other metallic materials with the ultra-fine grained (UFG) microstructure obtained by severe plastic deformation (SPD) techniques such as equal channel angular pressing (ECAP) have been in the spotlight of the material science and engineering community over the last few decades. Nevertheless, the data on environmental effects such as stress-corrosion cracking and hydrogen embrittlement (HE) on the performance of the UFG ferritic steels is still limited and is awaiting for clarification and thorough comprehensive examination. In the present study, the effect of the current density of cathodic hydrogen charging on the hydrogen concentration and state in the ECAPed and as-received low-carbon steel grade 09G2S has been investigated by the hot-extraction gas-analysis. It is found that due to the increased dislocation density and the total length (or volume fraction) of grain boundaries the ECAPed steel occludes much more hydrogen than its as-received counterpart at the same hydrogen charging conditions. Besides, the hydrogen concentration in the ECAPed steel is significantly changed at current densities below $20 \mathrm{~mA} / \mathrm{cm}^{2}$ only and is not affected by hydrogen-induced cracking. In contrast, the non-monotonous growth of the hydrogen concentration in the as-received steel occurs at the increasing current density up to $340 \mathrm{~mA} / \mathrm{cm}^{2}$ and is controlled by the extent of hydrogen-induced damage.

Keywords: severe plastic deformation, equal channel angular pressing, hydrogen concentration, steel, hydrogen embrittlement.

УДК: 538.911

\section{Влияние равноканального углового прессования и плотности тока катодного наводороживания на захват водорода в низкоуглеродистой стали}

\author{
Мерсон Е. Д. ${ }^{\dagger, 1}$, Мягких П. Н. ${ }^{1}$, Клевцов Г. В. ${ }^{1}$, Мерсон Д. Л. ${ }^{1}$, Виноградов А. Ю. ${ }^{2}$ \\ ${ }^{1}$ Научно-исследовательский институт прогрессивных технологий, Тольяттинский государственный университет, \\ ул. Белорусская, 14, Тольятти, 445667, Россия
}

${ }^{2}$ Кафедра механики и промышленности, Норвежский технологический университет, НТУ, Тронхейм, N-7491, Норвегия

Благодаря их выдающимся механическим свойствам, стали и другие металлические материалы с ультрамелкозернистой (УМЗ) микроструктурой, полученные методами интенсивной пластической деформации (ИПД), такими как, равноканальное угловое прессование (РКУП), находятся в центре внимания сообщества материаловедов в течение последних десятилетий. Тем не менее, данные о последствиях воздействия окружающей среды, таких как коррозионное растрескивание под напряжением и ВX, на характеристики УМЗ ферритных сталей ограничены в литературе и требуют дополнительных исследований. В настоящей работе при помощи газового анализа методом горячей экстракции было исследовано влияние плотности тока катодного наводороживания на концентрацию и состояние водорода в низкоуглеродистой стали марки 09Г2С в состоянии поставки и после РКУП. Обнаружено, что вследствие повышенной плотности дислокаций и общей длины границ зерен после РКУП сталь поглощает 
значительно более высокую концентрацию водорода, чем в состоянии поставки при данных условиях наводороживания. Кроме того, концентрация водорода в стали, подвергнутой РКУП, значительно изменяется только при плотностях тока ниже $20 \mathrm{~mA} / \mathrm{cm}^{2}$ и не зависит от водородо-индуцированного растрескивания. В то же время, в стали в состоянии поставки немонотонный рост концентрации водорода происходит при увеличении плотности тока до 340 мА/см² и контролируется степенью водородо-индуцированных повреждений.

Ключевые слова: интенсивная пластическая деформация, равноканальное угловое прессование, концентрация водорода, сталь, водородная хрупкость.

\section{Introduction}

A large group of deformation processing techniques collectively termed as severe plastic deformation (SPD) methods have been devised in materials science and engineering community in the last few decades for the fabrication of materials with enhanced properties $[1,2]$. An extreme grain refinement achieved in the course of SPD serves as a prerequisite for the significantly increased strength and fatigue resistance along with retaining reasonable ductility in many materials $[3,4]$. In particular, the SPD approach is of great importance when the desired strengthening effect cannot be achieved by conventional thermo-mechanical treatment, e.g. in low-alloy steels. For example, a five-times rise of the ultimate tensile strength up to $1500 \mathrm{MPa}$ has been reported for the $\mathrm{Fe}-0.01 \% \mathrm{C}$ alloy processed by high-pressure torsion [5]. However, high-strength steels are known to be highly susceptible to environmentally-assisted cracking and hydrogen embrittlement (HE) (the reader is referred to the recent review covering experimental and modelling aspects of the hydrogen effects in steels and highlighting existing challenges and open issues by Barrera et al. [6]). Concerning the HE phenomenon in iron-based alloys with the ultrafine grain (UFG) microstructure produced by SPD, the attention has been paid mostly to austenitic steels whose resistance to $\mathrm{HE}$ was either improved or not affected by SPD processing [7-9]. Mine et al. [9] demonstrated no change in the tensile strength of the SPD-processed specimens of 310 S austenitic stainless steel after high temperature gaseous charging up to 40 mass ppm concentration of hydrogen. The mitigation of hydrogen-induced ductility loss by ultrafine grain refinement has been found in 304 metastable austenitic stainless steel [7]. Astafurova et al. [8] concluded that the highly defective grain-subgrain microstructure with the high dislocation density alleviates hydrogen embrittlement effects in UFG $\mathrm{Cr}$-Ni-Mo and $\mathrm{Cr}$-Ni-Ti steels. A few publications concerning HE of UFG ferritic steels highlighted the detrimental effect of SPD grain refinement on their HE resistance $[5,10,11]$, though some guidelines for improvement have been proposed too [5]. Tareda et al. [11] found a significant increase in the HE susceptibility of ultra-low carbon interstitial free steel after SPD processing by accumulative roll-bonding. Merson et al. [10] showed that the ECAPed low-alloy steel grade 09G2S was much more susceptibility to HE than its as-received counterpart. Mine et al. demonstrated that the reduced HE resistance of the $\mathrm{Fe}-0.01 \% \mathrm{C}$ alloy processed by SPD can be entirely recovered by annealing which results in the decrease of the dislocation density and low-angle grain boundaries serving as hydrogen traps [5]. Despite the importance of the results of these studies, the data on HE in UFG steels is still scarce and the development of UFG steels with low susceptibility to hydrogen damages is still challenging.

The conventional approach to the investigation of the materials susceptibility to HE relies upon the assessing of the effect of hydrogen concentration on mechanical properties. The most popular and convenient laboratory way to vary the hydrogen concentration inside the steel specimens is cathodic charging under different electrolysis parameters such as current density, time, the chemical composition of an electrolyte, etc. To the author's best knowledge, the effect of cathodic hydrogen charging conditions on the hydrogen concentration and the state as well as on hydrogen-induced defects in UFG ferritic steels has not been studied as yet, albeit this information can provide a deeper insight into $\mathrm{HE}$ of these materials. The objective of the present experimental study was to assess the effect of the cathodic charging current density on the hydrogen concentration and the hydrogen state in the UFG low-alloy steel. Besides, the effect of the current density on hydrogen trapping the as-received counterpart of the present steel is of self-interest to gain a better understanding of the hydrogen trapping process and the nature of HE in steels.

\section{Experimental}

Commercial low-alloy steel grade 09G2S was received as hot-rolled bars of $20 \mathrm{~mm}$ diameter. Some of the as-received bars were subjected to thermo-mechanical treatment through the following procedure: (1) homogenizing annealing at $810^{\circ} \mathrm{C}$ followed by quenching in water, (2) tempering at $450^{\circ} \mathrm{C}$, (3) cold severe plastic deformation by the "CONFORM" ECAP (equal channel angular pressing) [12] process to 4 passes by the $\mathrm{Bc}$ route and (4) annealing at $350^{\circ} \mathrm{C}$ for residual stress removing. The chemical composition and mechanical properties of these as-received and ECAPed steels before and after hydrogen charging have been recently reported in [10] and are not discussed in the present paper. The flat rectangular specimens with $20 \times 4 \times 2.1 \mathrm{~mm}^{3}$ dimensions were cut from the as-received and ECAPed bars by the electric-discharge machine and grounded by emery paper to the \#240 grade.

Cathodic hydrogen charging was performed in the $5 \% \mathrm{H}_{2} \mathrm{SO}_{4}+1.5 \mathrm{~g} / 1$ of thiourea solution at current densities ranging from 0.3 to $600 \mathrm{~mA} / \mathrm{cm}^{2}$ for 1 hour. A platinum wire was used as an anode. Within 2 minutes after hydrogen charging the specimens were washed in running water, dried by hot air, rinsed in $\mathrm{CCl}_{4}$ and subjected to thermal desorption analysis.

The concentration and desorption kinetics of diffusible hydrogen was investigated by the carrier gas hot-extraction 
method using the gas-analyzer Galileo G8 (Bruker) with the 99.999\% pure nitrogen carrier gas. During the gas-analysis, each specimen was heated up to $200^{\circ} \mathrm{C}$ in $\mathrm{N}_{2}$ gas flux with the heating rate of $17^{\circ} \mathrm{C} / \mathrm{min}$ and held at the destination temperature for $15 \mathrm{~min}$. The extraction curves representing the desorption rate of hydrogen as a function of time were recorded during the test.

The metallographic examination of the specimen's surface and microstructure was carried out by using the confocal laser scanning microscope (CLSM) Lext OLS4000 (Olympus) and the scanning electron microscope (SEM) SIGMA (Zeiss) equipped with the EDAX/TSL electron backscattering diffraction (EBSD) detectors and software.

\section{Results}

\subsection{Microstructure}

The metallographic study showed that the as-received steel had a typical ferrite-pearlite microstructure with coarse grains of $10 \mu \mathrm{m}$ average diameter and various non-metallic inclusions including elongated MnS, Fig. 1a. The ECAP results in the substantial grain refinement down to $0.6 \mu \mathrm{m}$ as is evidenced by the inverse pole figure (IPF) map, which was obtained by the EBSD technique and is shown in Fig. $1 b$. The dislocation cell substructure and the fine grains separated by low and high angle boundaries are clearly visible on this image. It is also established that the microstructure is much more distorted in the regions close to the side surface of the ECAPed bars.

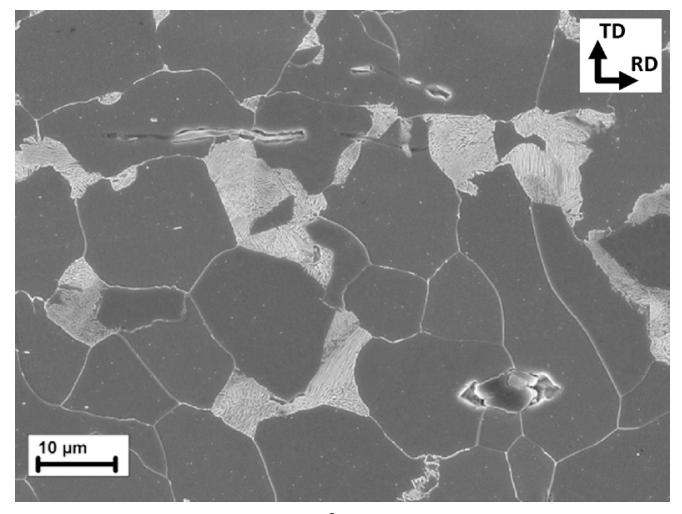

a

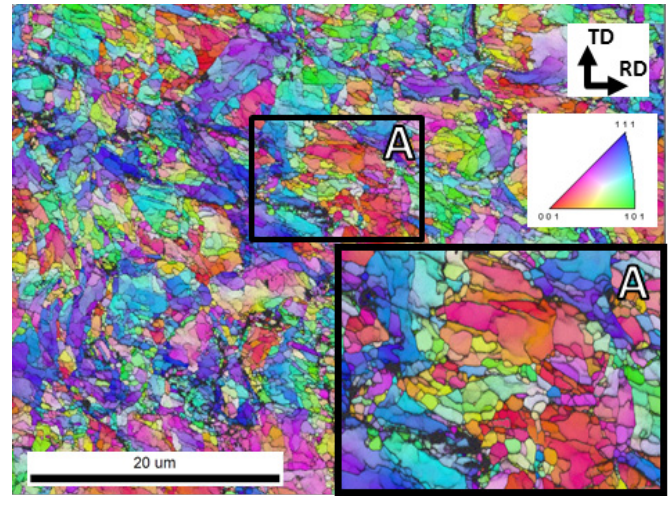

$\mathrm{b}$

Fig. 1. (Color online) SEM (a) and EBSD inverse pole figure (IPF) maps (b) images representing microstructure of the as-received (a) and the ECAPed steels (b).

\subsection{Hydrogen-induced damage}

In the as-received steel, hydrogen charging produces typical hydrogen-induced cracks (HICs) and blisters (HIBs) which are represented in Fig. $2 \mathrm{a}$ and $3 \mathrm{a}-\mathrm{d}$. As can be seen in Fig. $3 \mathrm{a}-\mathrm{d}$, the number of HIBs on the as-received specimen's surface strongly depends on the hydrogen charging current density. Few small HIBs are observed on the specimens which were hydrogen charged at the current densities below $280 \mathrm{~mA} / \mathrm{cm}^{2}$, Fig. $3 \mathrm{a}$. After charging at higher current densities, the number and the size of HIBs increase progressively, Fig. 3b, c, until the extent of hydrogeninduced damage becomes unchanged at current densities above $340 \mathrm{~mA} / \mathrm{cm}^{2}$, Fig. $3 \mathrm{c}$, d.

Regardless of the applied current density, no HIBs are found on the surface of the ECAPed specimens, c.f. Fig. 3 e, f. Nevertheless, some of the ECAPed specimens contained thin and sharp HICs demonstrating the overall more brittle appearance in comparison to those in the as-received specimens. Besides, in contrast to the as-received steel, the number and size of the HICs in the ECAPed steel were not dependent on the hydrogen charging current density, Fig. 2 b. Presumably, the presence of the HICs was related to the strong heterogeneity of the microstructure of the ECAPed steel.

\subsection{Hydrogen concentration}

The gas-analysis showed that the concentration of diffusible hydrogen in the as-received steel grows from 1.7 to $12 \mathrm{ppm}$ as the current density increases from 20 to $340 \mathrm{~mA} / \mathrm{cm}^{2}$, Fig. $4 \mathrm{a}$.
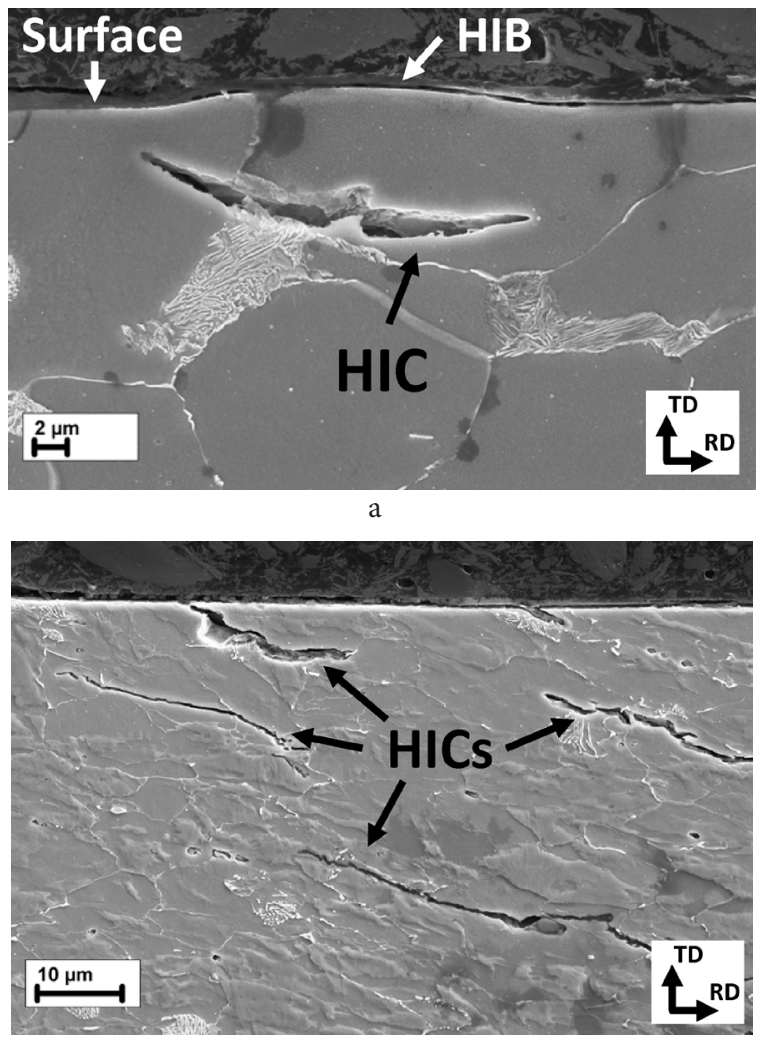

b

Fig. 2. SEM images representing the hydrogen-induced cracks (HICs) and blisters (HIBs) in the microstructure of the as-received (a) and ECAPed steels (b). 


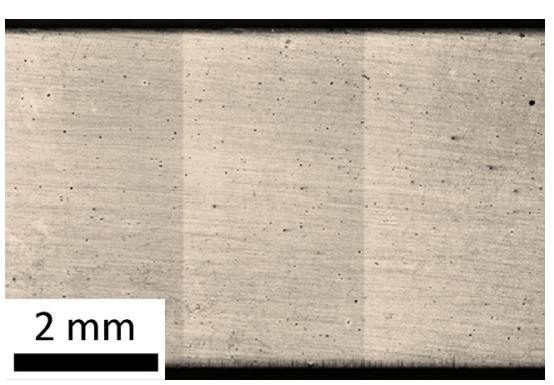

a

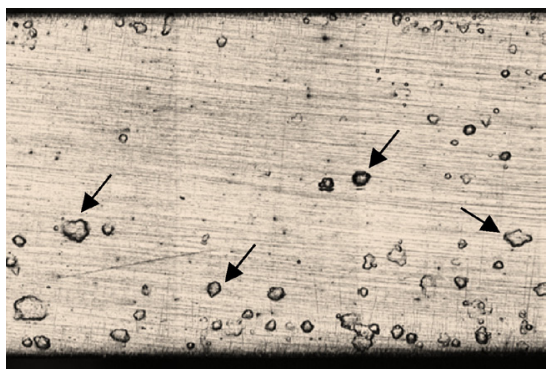

$\mathrm{d}$

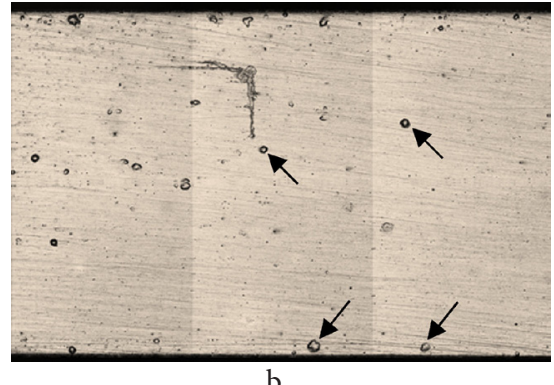

b

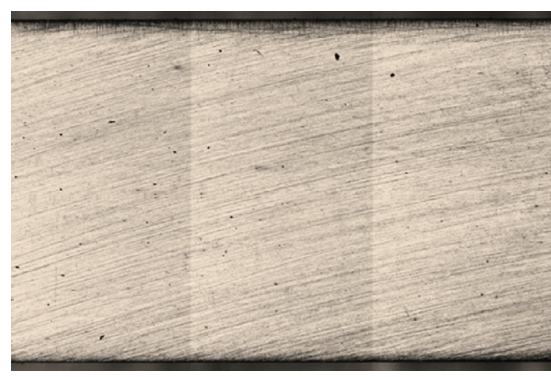

e

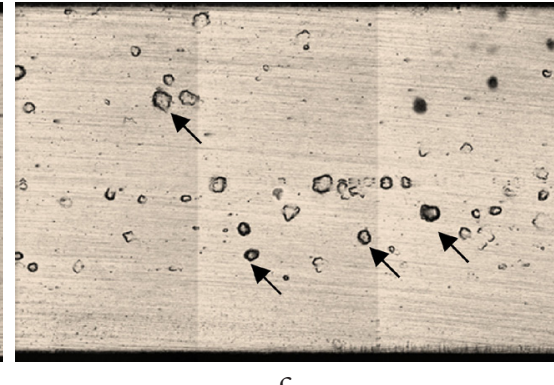

c

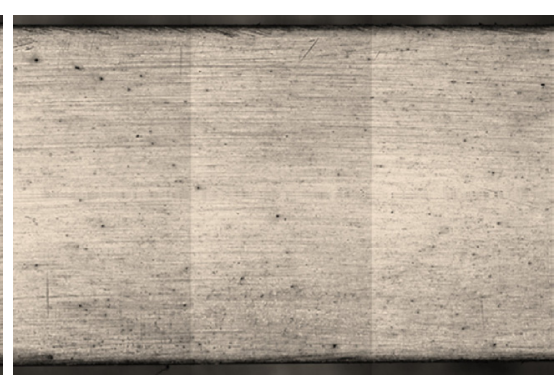

f

Fig. 3. Panoramic CLSM images representing the surface of the as-received $(\mathrm{a}-\mathrm{d})$ and the ECAPed $(\mathrm{e}, \mathrm{f})$ specimens after hydrogen charging at different current densities: 260 (a), 280 (b), 340 (c), 600 (d, f), $200 \mathrm{~mA} / \mathrm{cm}^{2}$ (e). The arrows on the images indicate the hydrogen-induced blisters.

However, as follows from Fig. $4 \mathrm{a}$, the dependence of the hydrogen concentration on the current density is non-monotonous. After the linear steady increase of hydrogen content from 1.7 to $4.5 \mathrm{ppm}$ in the $20-260 \mathrm{~mA} / \mathrm{cm}^{2}$ range, the growth of hydrogen concentration is steeply enhanced until it reaches $12 \mathrm{ppm}$ at $340 \mathrm{~mA} / \mathrm{cm}^{2}$. At the current densities between 340 and $600 \mathrm{~mA} / \mathrm{cm}^{2}$, the significant scattering of the hydrogen concentration is observed though, on average, it is only slightly changed. It is important to note that both the intensive blistering and intensive growth of the hydrogen concentration in the as-received steel occur in the same current density range.

As follows from Fig. $4 \mathrm{a}$, the ECAPed steel occludes much higher concentration of hydrogen at a given current density than the as-received one. In the ECAPed steel, the pronounced increase in the hydrogen concentration from 6 to $16 \mathrm{ppm}$ occurs in the current density range from 0.3 to $20 \mathrm{~mA} / \mathrm{cm}^{2}$, while the further increase of the current density up to $600 \mathrm{~mA} / \mathrm{cm}^{2}$ results in only negligible growth of the hydrogen concentration.

\subsection{Hydrogen evolution kinetics}

The extraction curves for each as-received and ECAPed specimen exhibit one asymmetric desorption peak indicating desorption of hydrogen in the temperature range from 25 to $200^{\circ} \mathrm{C}$ with the maximum desorption rate at the temperature varying from 90 to $150^{\circ} \mathrm{C}$. It can be seen in Fig. 5 a that for the as-received specimens the increase of the current density results in the increase of the peak height and area as well as in the growth of the high temperature "hump" visible on the right-hand side of the extraction curve. The appearing of this concave "hump" results in the shifting of the desorption peak centroid towards the higher temperature. It is obvious from Fig. $4 \mathrm{~b}$ that for the as-received steel the dependence of the centroid temperature on the current density is quite similar to that of the hydrogen concentration, Fig. 4 a. Just as the hydrogen concentration behaves, the centroid temperature monotonously and relatively slowly grows with the increasing current density up to $260 \mathrm{~mA} / \mathrm{cm}^{2}$. Then, it steeply rises in the range from 260 to $340 \mathrm{~mA} / \mathrm{cm}^{2}$ and, finally, reaches a saturation level at $340-600 \mathrm{~mA} / \mathrm{cm}^{2}$ current densities. The centroid temperatures of the hydrogen desorption peaks for the ECAPed steel are mostly higher than those for the as-received steel, particularly, at low current densities, Fig. $4 \mathrm{~b}$ and $5 \mathrm{~b}$. However, significant scattering of the experimental points does not allow establishing any firm dependence between the centroid temperature and the current density.

\section{Discussion}

It follows from the obtained results that the hydrogen concentration in the as-received steel correlates with the extent of hydrogen-induced damage represented by HICs and HIBs. Apparently, at some critical current density, which in the present study is about $260 \mathrm{~mA} / \mathrm{cm}^{2}$, the pressure of the hydrogen gas, accumulated inside some discontinuities of the as-received steel, becomes high enough to activate intensive hydrogen-induced cracking and blistering [13], which, in turn, cause the substantial increase in the hydrogen trapping capacity of this steel. Indeed, the formation of a HIB, associated with the underlying HIC implies the creation of a new free internal volume that can be filled with molecular hydrogen. Besides, plastic deformation of the metal surrounding the HIC provides the increasing density of dislocations, which are known as effective hydrogen traps for diffusible hydrogen. In particular, the presence of hydrogen inside HICs as well as in the $50 \mu \mathrm{m}$ radius zone around them has been evidenced by neutron tomography in pure iron [14]. Another fact witnessing for hydrogen trapping 
at HICs in the as-received steel is the increase of centroid temperature of the hydrogen desorption peak with the increasing hydrogen concentration and the current density. According to the literature data, the hydrogen desorbing from low-carbon steel in the temperature range between 25 and $200^{\circ} \mathrm{C}$ can be coming from ferritic grain boundaries, ferrite-cementite interfaces and dislocations $[15,16]$. During heating of a hydrogen charged specimen, the evolution of hydrogen from all of these traps results in overlapping desorption peaks on the extraction curve. Superposition of such individual peaks gives the asymmetric shape of the resultant peak such as those observed in the present study, Fig. 5. It is known that the evolution of hydrogen from dislocations occurs at a higher temperature than from ferriteferrite and ferrite-cementite interfaces $[15,16]$. Thereby, providing that grain and phase boundaries in the as-received steel are not affected by hydrogen charging, the increasing fraction of hydrogen trapped at dislocations around the HICs should shift the centroid of the entire desorption peak towards higher temperatures. The observed in the present study relationship between the hydrogen concentration and the centroid temperature indicates that hydrogen trapping at dislocations surrounding the HICs is probably the key process controlling the hydrogen concentration in the as-received steel in the wide current density range, i.e. at least from 20 to $600 \mathrm{~mA} / \mathrm{cm}^{2}$.

The ECAPed steel has much finer grain size and the substantially larger dislocation density than the as-received

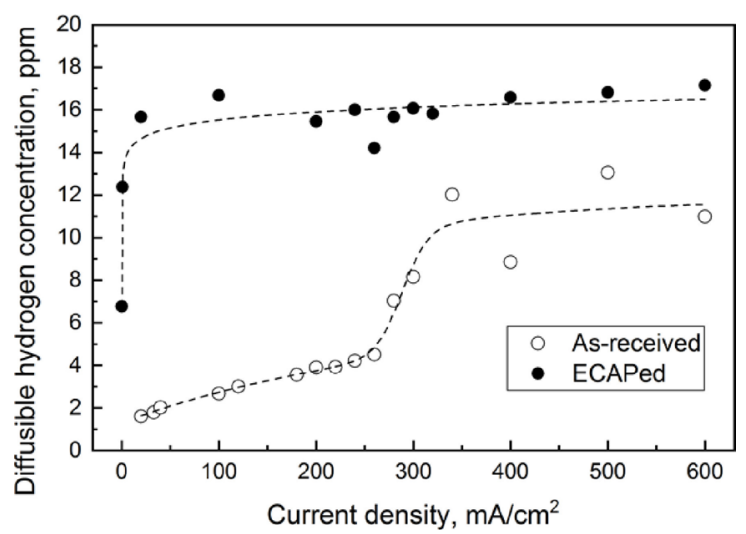

a

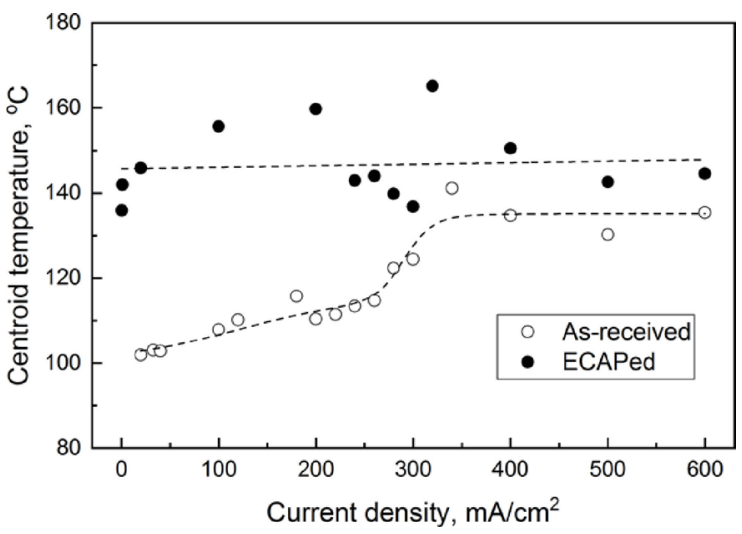

$\mathrm{b}$

Fig. 4. Effect of the current density of cathodic hydrogen charging on the diffusible hydrogen concentration (a) and the centroid temperature of hydrogen desorption peaks (b) for the as-received and ECAPed specimens. one. Thus, at low current densities, at which the extent of hydrogen-induced damage in the as-received steel is negligible, the ECAPed steel can uptake much higher hydrogen than the as-received one. The high centroid temperature of the desorption peak of the ECAPed steel can be explained by the large portion of hydrogen being trapped at dislocations, which might be produced during SPD. On the other hand, due to the high strength and the initially extremely high plastic strain imposed onto the ECAPed steel bar, apparently, hydrogen-induced cracking does not produce any significant increase in the dislocation density in this steel. Thus, the hydrogen concentration is only slightly changed as the current density increases from 20 up to $600 \mathrm{~mA} / \mathrm{cm}^{2}$. Large scattering of the centroid temperature of the desorption peak can likely be explained by the strong heterogeneity of the ECAPed steel microstructure.

The obtained results update the existing experimental database with new information about the hydrogen behaviour in the fine-grain ferritic steel processed by ECAP. It is documented that the effect of the current density on the hydrogen concentration in the ECAPed steel is significantly different from that in its coarse-grain counterpart. It is plausible to expect a qualitatively similar dependence of hydrogen concentration on the current density for the ferritic steels processed by other SPD techniques. However, the quantitative characterization and, most importantly, modelling of such dependencies requires additional investigations and will be considered in further studies.
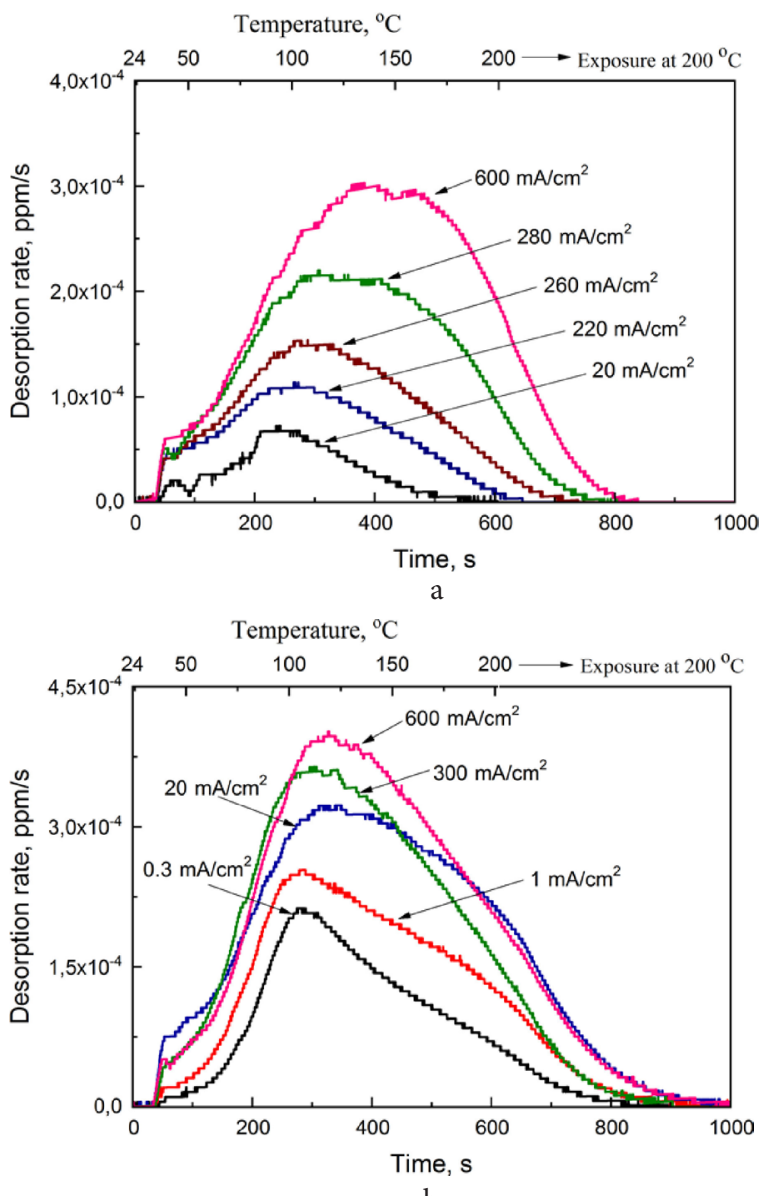

b

Fig. 5. (Color online) Effect of the current density on hydrogen extraction curves for the as-received (a) and ECAPed (b) specimens. 


\section{Conclusions}

1. The low-alloy steel grade 09G2S subjected to equal channel angular pressing (ECAP) occludes more diffusible hydrogen than the same steel in the as-received hot-rolled state at the same cathodic hydrogen charging conditions. The high hydrogen-uptake capacity of the ECAPed steel is due to the increased density of grain boundaries and dislocations - both serving as traps for diffusible hydrogen.

2. Hydrogen-induced cracking and blistering caused by cathodic hydrogen charging in the as-received steel grade 09G2S are accompanied by significant plastic deformation increasing the dislocation density and, thus, rising the hydrogen trapping capacity. In contrast to the as-received steel, the hydrogen-induced damage in the ECAPed steel does not produce a significant rise in the dislocation density and the corresponding hydrogen trapping capacity.

3. The dependence of the diffusible hydrogen concentration in the as-received steel grade 09G2S on the current density of cathodic hydrogen charging has a nonlinear sigmoidal shape featuring by three distinct parts: (i) the linear steady growth of the hydrogen concentration between 20 and $260 \mathrm{~mA} / \mathrm{cm}^{2}$ followed by (ii) the steep increase in the hydrogen concentration from 260 to $340 \mathrm{~mA} / \mathrm{cm}^{2}$ and (iii) the saturation plateau from 340 to $600 \mathrm{~mA} / \mathrm{cm}^{2}$. As opposed to the as-received steel, the significant change in the hydrogen concentration in the ECAPed steel occurs at current densities below $20 \mathrm{~mA} / \mathrm{cm}^{2}$ only.

Acknowledgements. The authors appreciate the help of the research team of Prof. R. Z. Valiev (Ufa State Aviation Technical University) for providing the ECAPed material.

\section{References}

1. R. Valiev. Nanostructuring of metals by severe plastic deformation for advanced properties. Nat. Mater. 3, 511 (2004). Crossref
2. A. Azushima, R. Kopp, A. Korhonen, D. Y. Yang, F. Micari, G. D. Lahoti, et al. CIRP Ann. 57, 716 (2008). $\underline{\text { Crossref }}$

3. A. Vinogradov. Adv. Eng. Mater. 17, 1710 (2015). Crossref

4. Y. Estrin, A. Vinogradov. Acta Mater. 61, 782 (2013). Crossref

5. Y. Mine, S. Matsumoto, Z. Horita. Corros. Sci. 53, 2969 (2011). Crossref

6. O. Barrera, D. Bombac, Y. Chen, T. D. Daff, E. GalindoNava, P. Gong, et al. J. Mater. Sci. 53, 6251 (2018). $\underline{\text { Crossref }}$

7. Y. Mine, N. Horita, Z. Horita, K. Takashima. Int. J. Hydrogen Energy. 42, 15415 (2017). Crossref

8. E.G. Astafurova, E. V. Melnikov, S.V. Astafurov, I.V. Ratochka, I.P. Mishin, G. G. Maier, et al. Phys. Mesomech. 22, 313 (2019). Crossref

9. Y. Mine, K. Tachibana, Z. Horita. Metall. Mater. Trans. A. 42, 1619 (2011). Crossref

10. E.D. Merson, P.N. Myagkikh, G.V. Klevtsov, D. L. Merson, A. Vinogradov. Eng. Fract. Mech. 210, 342 (2019). Crossref

11. D. Tareda, N. Takata, N. Tsuji. Susceptibility to Hydrogen Embrittlement of Ultrafine Grained IF Steel Produced by Severe Plastic Deformation. In: 214th ECS Meet. Electrochemical Society, Honolulu, Hawaii (2008) p. 1.

12. G.I. Raab, R.Z. Valiev, D.V. Gunderov, T.C. Lowe, A. Misra, Y.T. Zhu. Mater. Sci. Forum. 584-586, 80 (2008). Crossref

13. M. C. Tiegel, M. L. Martin, A. K. Lehmberg, M. Deutges, C. Borchers, R. Kirchheim. Acta Mater. 115, 24 (2016). Crossref

14. A. Griesche, E. Dabah, T. Kannengiesser, N. Kardjilov, A. Hilger, I. Manke. Acta Mater. 78, 14 (2014). Crossref

15. W.Y. Choo, J. Lee. Metall. Trans. A. 13, 135 (1982). Crossref

16. W. Y. Choo, J. Lee. J. Mater. Sci. 17, 1930 (1982). $\underline{\text { Crossref }}$ 